\title{
ADRENERGIC MECHANISM IN TETRAHYMENA II EFFECT OF ADRENALINE ON CELL PROLIFERATION
}

\author{
Heitaroh IWATA, Kimio KARIYA and Yutaka WADA* \\ Department of Pharmacology, Faculty of Pharmaceutical Sciences, \\ Osaka University, Toneyama, Toyonaka, Osaka, Japan
}

Accepted March 5, 1973

\begin{abstract}
Growth of Tetrahymena in the exponential phase was slightly accelerated by transfer of cells to a medium containing $10^{-3}-10^{-5} \mathrm{M}$ adrenaline or noradrenaline, while that of stationary phase cells was inhibited by $10^{-3}-10^{-7} \mathrm{M}$ catecholamine. In synchronized cultures of Tetrahymena, adrenaline inhibited RNA and protein syntheses in both the late $G_{1}$ and the $G_{2}$ phases. These inhibitory effects in the late $G_{1}$ and $G_{2}$ phases result in an inhibition of the introduction of the $S$ phase and of cytokinesis, respectively. These results indicate that an adrenergic mechanism in Tetrahymena plays a role in regulating the cell cycle.
\end{abstract}

Earlier reports on the role of catecholamines on cell proliferation showed that chronic administration of isoproterenol induced hyperplasia of the salivary glands in rats (1) and mice (2). Barker (3) and Beserga (4) reported that a single injection of isoproterenol resulted in increased DNA synthesis in rodent salivary gland after a lag period of about 20 hr. On the other hand, adrenaline is known to depress mitotic activity in a variety of tissues (5) and to inhibit DNA synthesis in regenerating rat liver (6).

As reported by the authors (7) and others (8), Tetrahymena pyriformis, like mammals, has pathways for both biosynthesis and degradation of catecholamines. Recently, we observed (9) that monoamine oxidase activity decreased in the exponential growth phase and increased in the stationary phase. Furthermore, in synchronized cultures, the enzyme activity was shown to decrease in the $\mathrm{M}$ and $\mathrm{S}$ phases.

The present study was on the role of the adrenergic mechanism in the growth of Tetrahymena.

\section{MATERIALS AND METHODS}

Methods for culturing and synchronization in Tetrahymena pyriformis W were the same as reported previously (9).

For experiments on the effect of adrenaline and noradrenaline on growth, cells in the exponential and the stationary growth phase were obtained by culture for 24 and 96 hr respectively. These cells were then transferred to a fresh medium containing a test drug, and after incubation for $24 \mathrm{hr}$ the cell number was determined electronically using

* Present adress: Pharmaceutical Rescarch Laboratory, Sakai Chemical Industry Co., Ltd., Matsugaoka-nakamachi, Kawachinagano, Osaka, Japan. 
a Coulter Counter, Model B. The growth rate is expressed as a percentage of the control cell count.

To determine the protein and nucleic acid contents, synchronized cultures of Tetrahymena were incubated with or without adrenaline $\left(5 \times 10^{-5} \mathrm{M}\right)$ at $26^{\circ} \mathrm{C}$. Samples were removed by pipettc cvery $15 \mathrm{~min}$. Nucleic acid was extracted by the procedure of Schneider (10). RNA was measured by the method of Mcjbaum (11) and DNA by that of Ceriotti (12). Protein was determined by the melhod of Lowry et al. (13).

To study labeling of protein and nuclcic acid by the radioactive precursor, synchronized cells were incubated at $26^{\circ} \mathrm{C}$ with the precursor $(50 \mathrm{~m} / \mu \mathrm{Ci} / \mathrm{ml})$ and various test drugs $(5 \times$ $\left.10^{-5} \mathrm{M}\right)$ affecting the adrenergic mechanism. Drugs were added just after, or $55 \mathrm{~min}$ after the end of heat treatment (EIIT). Incorporation of radioactive compounds was measured by the rapid radioassay technique of Byfield et al. (14), and radioactivity was determined using an Aloka Gas Flow Counter.

Tested were the effects of the following drugs; 1-adrenaline (E. Merck, Darmstadt), Catron (Chugai Pharmaceutical Co,, Ltd., Tokyo), dl-noradrenaline and DL-dihydroxyphenylalanine (DOPA, Nakarai Chemicals Ltd., Kyoto). The radioactive precursors used for studies on protein, RNA and DNA synthesis, respectively, were uniformly labeled L-leucinc- ${ }^{14} \mathrm{C}(212 \mathrm{mCi} / \mathrm{mmol})$, uracil- $2{ }^{14} \mathrm{C}(21 \mathrm{mCi} / \mathrm{mmol})$ and thymidine- $2-{ }^{14} \mathrm{C}(51 \mathrm{mCi} /$ mmol). These compounds were obtained from Daiichi pure Chemicals Co., Ltd., Tokyo.

\section{RESULTS}

1) Effects of adrenatine and noradrenaline on growth of Tetralymena

As shown in Fig. 1, when cells in the exponential growth phase were cultured in a fresh medium for $24 \mathrm{hr}$, the growth was slightly accelerated by adrenaline at a concentration of $10^{-3}-10^{-5} \mathrm{M}$ but was not influenced by adrenaline at a concentration of less than

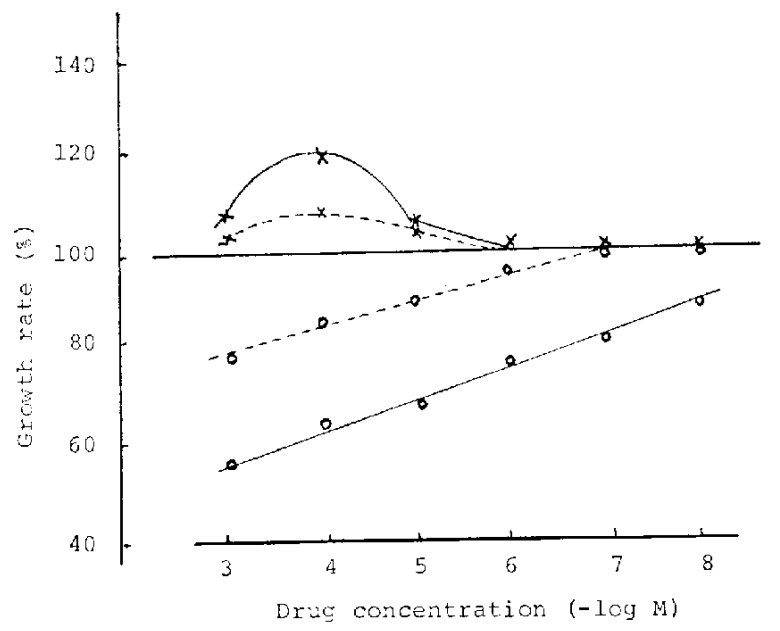

FiG. 1. Effect of catecholamines on growth of Tetrahymena.

$-x-$, exponential phase cells; $-\mathrm{O}_{-}$, stationary phase cells. Solid

line, with adrenaline; dotted line, with noradrenaline. 
$10^{-6} \mathrm{M}$. When stationary phase cells were cultured under the same conditions however, the growth was inhibited at concentrations of $10^{-3} \cdot 10^{-5} \mathrm{M}$ adrenaline. Under the same conditions noradrenaline had a similar, though somewhat weaker effect than adrenaline.

2) Influstere of adienaline on the DNA, RNA and protein contents of synchronized cultures

Microscopic examination showed that in synchronized cultures, cytokincsis began about 60 min after EIIT, and as shown in

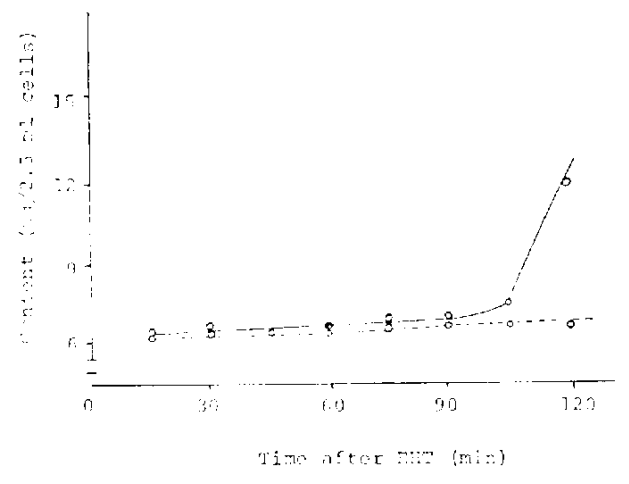

Frc. 2. Effect of adrenaline on the DNA content of synchronized cultures.

Solid line, untreated cells; dotted line, cells treated with adrenaline.

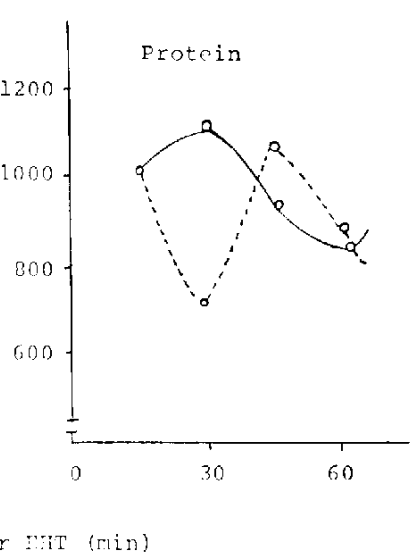

FIci. 3. Effect of adrenaline on protein and RNA contents of synchronized cultures. Conditions as in Fig. 2.

Fig. 2, DNA replication began about $90 \mathrm{~min}$ after E.HT. Cytokinesis or induction of DNA synthesis were not observed in cells treated with adrenaline. Curves for RNA and protein contents before cytokinesis also changed with addition of adrenaline (Fig. 3).

3) Inthibition of protein and mucteic acid symthesis by adrombe

For comparison, DOPA and Catron were tested. In this experiment, radionctive compounds were added just after EIIT. Various drugs were added immediately or 55 min after EHT.

(a) Effects of druss alded at EHT: Observations were carried out for 120 min. Time couse for incorporation of each precursor is shown in Figs. 4-6. In the control, cell protein synthesis started immediately after EHT and rose rapidly after $60 \mathrm{~min}$, at which time cytokinesis was microscopically observed. Addition of adrenaline, DOPA or Catron depressed the incorporation. 


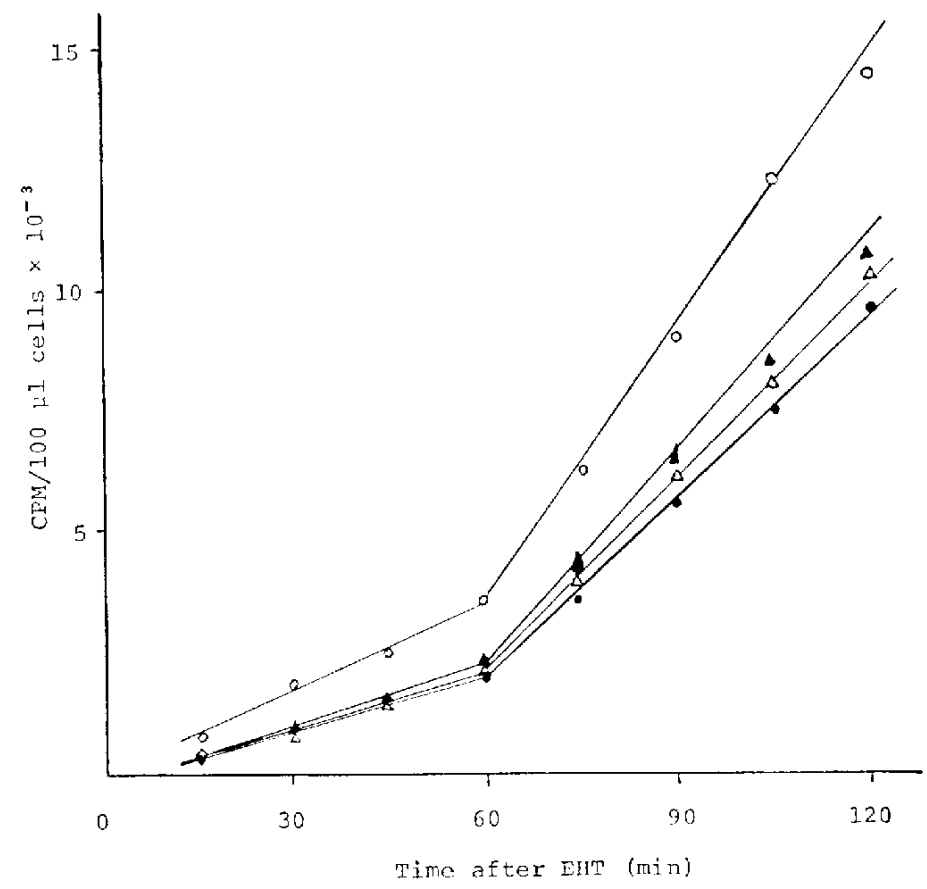

FIG. 4. Effects of various drugs added at EIIT on incorporation of ${ }^{14} \mathrm{C}$-leucine into trichloroacetic acid insoluble material in synchronized cultures.

-0 , control ; - --, adrenaline ; $-\longrightarrow$, DOPA ; $-\mathbf{\Lambda}$, Catron. Drugs were present at concentrations of $5 \times 10^{-1} \mathrm{M}$ and a radioactive precursor (50 $\left.\mathrm{m} / / \mathrm{Ci}_{i} \mathrm{ml}\right)$ was added just after EHT.

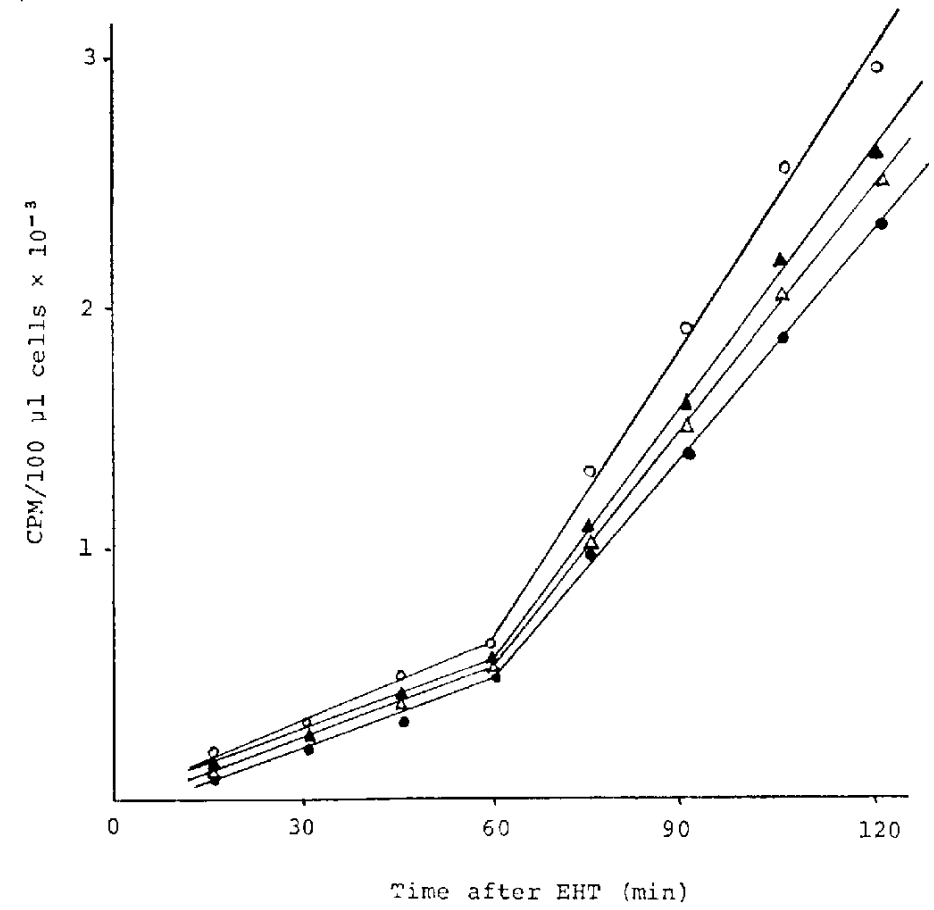

Fici. 5. Effects of various drugs added at EHT on incorporation of ${ }^{11} \mathrm{C}$-uracil into trichloroacetic acid insoluble material in synchronized cultures.

Conditions and symbols as in Fig. 4. 


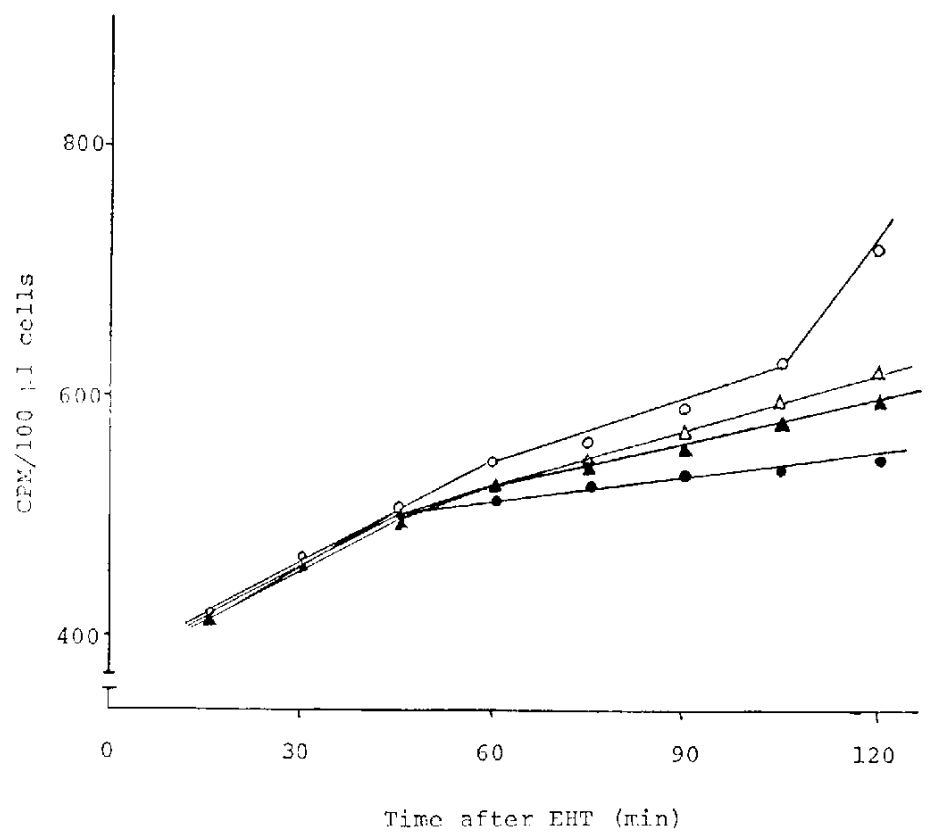

FIc. 6. Effects of various drugs added at EHT on incorporation of ${ }^{14} \mathrm{C}$-thymidine into trichloroacetic acid insoluble material in synchronized cultures.

Conditions and symbols as in Fig. 4.

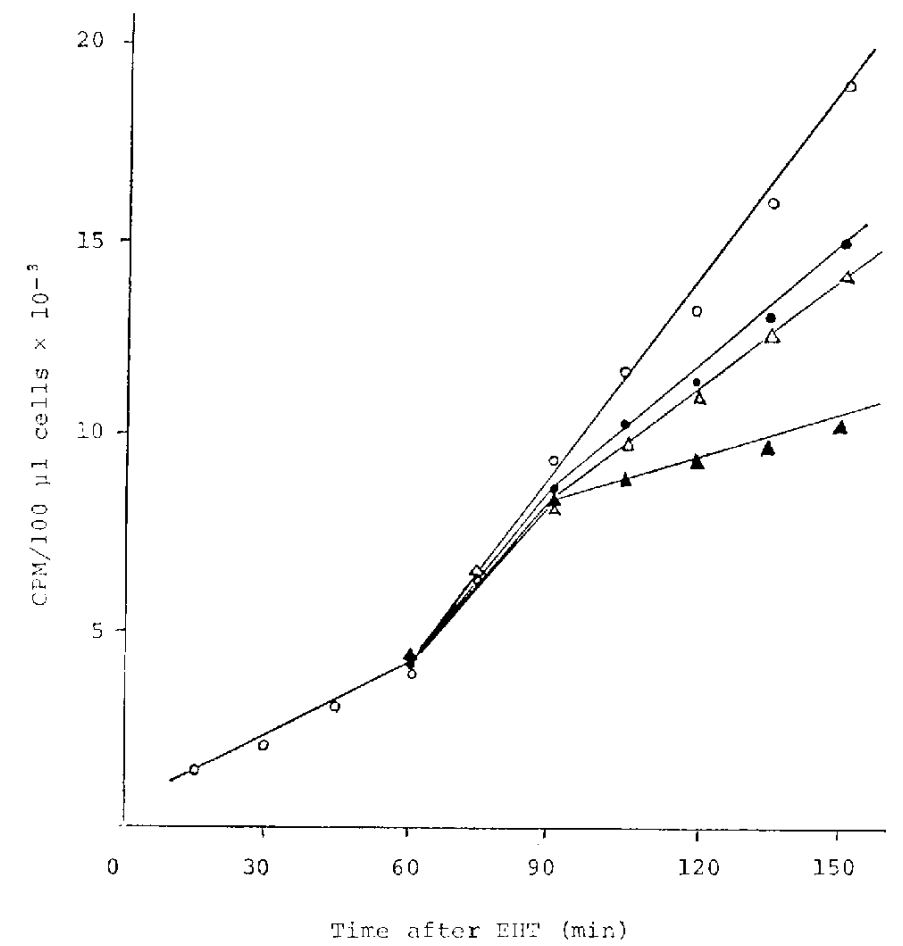

Fig. 7. Effects of various drugs added 55 min after EHT on incorporation of ${ }^{14} \mathrm{C}$ leucine into trichloroacetic acid insoluble material in synchronized cultures.

Conditions and symbols as in Fig. 4. 


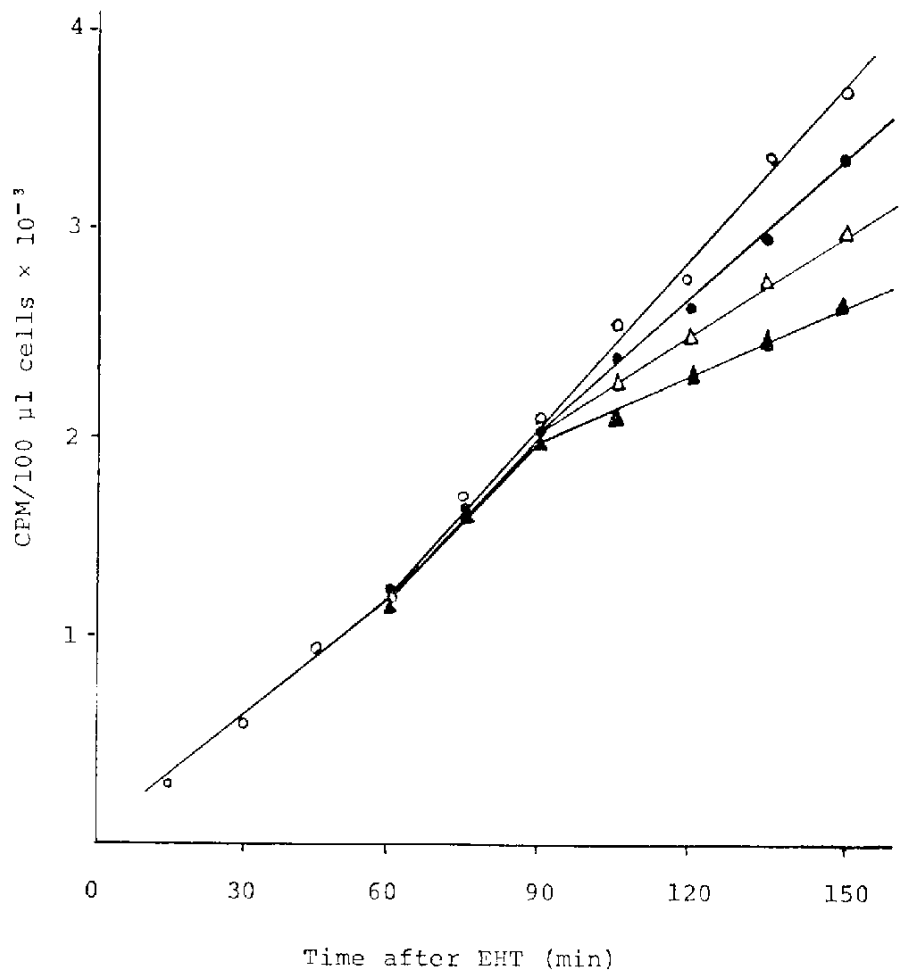

Fir. 8. Effects of various drugs added 55 min after EHT on the incorporaion of ${ }^{14} \mathrm{C}$-uracil into trichloroacetic acid insoluble material in synchronized culturcs. Conditions and symbols as in Fig. 4.

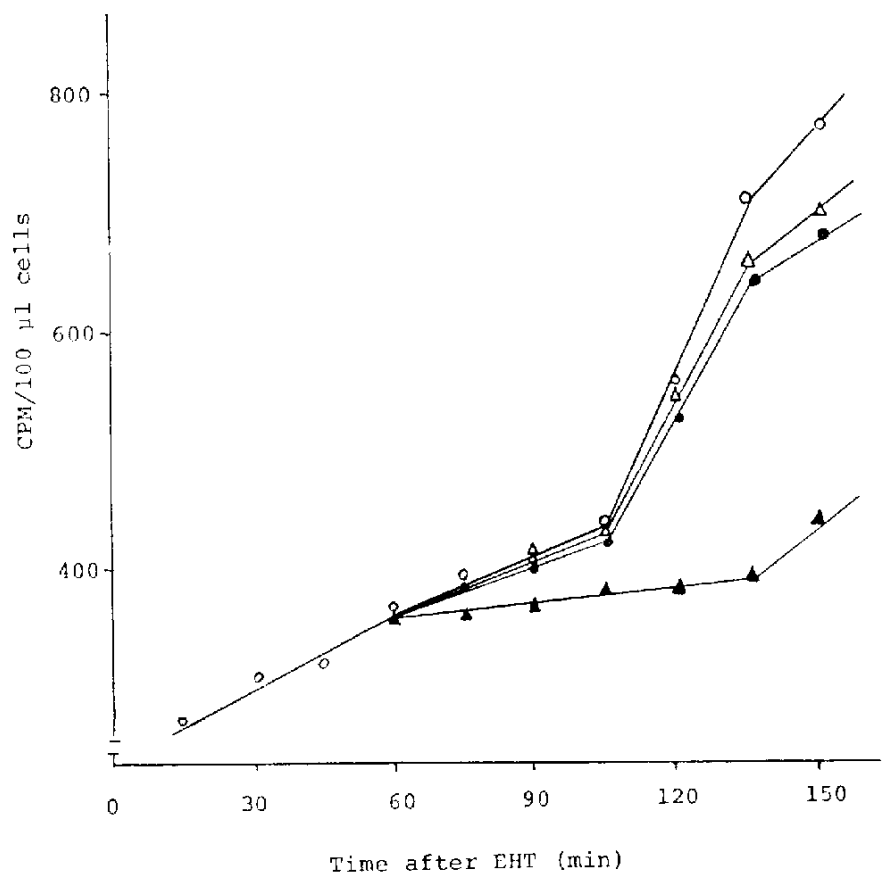

FiG. 9. Effects of various drugs added $55 \mathrm{~min}$ after EHT on incorporation of ${ }^{14} \mathrm{C}$ thymidine into trichloroacetic ac!d insoluble material in synchronized cultures. Conditions and symbols as in Fig. 4. 
Inhibitory effects of these drugs on RNA synthesis were similar, although weaker than the effects on protein synthesis.

Incorporation of ${ }^{14} \mathrm{C}$-thymidine also began after EHT in both control cells and those treated with drugs. The slope of the incorporation curve for control cells decreased after 60 min and increased again after $105 \mathrm{~min}$. On treatment with drugs, the curves for incorporation were depressed relative to that of the control and further increase was not observed. Adrenaline caused the greatest inhibition, the effect being observed after 45 min.

(b) Effects of drugs added $55 \mathrm{~min}$ after EHT: Observations were made for $150 \mathrm{~min}$, and results are shown in Figs. 7-9. The rate of incorporation of radioactive precursors into protein and RNA were the same in cultures with and without drugs until approx. 90 min after EHT, after which incorporation was inhibited. Catron had the most inhibitory effect. The incorporation of ${ }^{14} \mathrm{C}$-thymidine into cells treated with drugs other than Catron was the same as that into control cells for about 105 min after which inhibition was observed. In cells treated with Catron, DNA synthesis was depressed after 60 min but after 135 min began a gradual increase.

\section{DISCUSSION}

In connection with the relationship between adrenaline and cell proliferation, Bullough et al. (15) showed that the diurnal rhythm of the mitotic rate in the epidermis was inversely related to that of adrenaline secretion. Subsequently, they (16) suggested that an adrenaline-chalone complex may be formed and act as a sort of tissue-specific repressor in the tissue concerned. Further, Sakuma ef al. (6) suggested that in regenerating rat liver, adrenaline may interfer with a stage proceeding the S phase, presumably the "dicho-phase", and this would lead to the inhibition of mitosis.

In this work, evidence that the growth of Tetrahymena is sensitive to catecholamines was obtained. Namely, when cells were transferred to a fresh medium containing adrenaline or noradrenaline, growth of cells in the exponential phase was slightly accelerated, while that of cells in the stationary phase was inhibited. In relation to this result, it was observed that the catecholamine content and the rate of the conversion of radioactive tyrosine into catecholamines were higher in cells in the exponential than in the stationary phase (17). This cvidence indicates that catecholamines in Tetrahymena play an important role in growth and may be very closcly related to regulation of proliferation in the prolozoan.

Results of chemical assays of the nucleic acic and protein contents of synchronized cultures of Tetrahymona indicate that adrenaline participates in RNA and protein metabolism in the $\mathrm{G}_{2}$ phase, a phase beforc cytokinesis. Further, adrenaline inhibits the incorporation of radioactive leucine and uracil into protein and $R N A$, respectively in the late $G_{1}$ and $G_{2}$ phases. The drug also inhibits DNA synthesis, presumably due to inhibitory effects on protein and RNA syntheses, as mentioned above.

Hence, the growh of Tetrahymena may be regulated at wo points in the cell cycle 
by the adrenergic mechanism. One point is RNA and protein syntheses in the late $\mathrm{G}_{1}$ phase, which are essential for the DNA synthesis as reported by Taylor (18). The other point is the $G_{2}$, synthesis of RNA and protein of the division apparatus which is required for the introduction of the $M$ phase $(19,20)$. It is of interest at this point, that Frankfurt (21) observed that chalone influenced the proliferation rate of the scuamous epithelium of the forestomach in mice by inhibiting two transition points in the cell cycle: $G_{2} \rightarrow M$ and $G_{1} \cdot S$. These findings may relate to the fact that in populations of quiescent cells almost all cells are found to be in the $G_{1}$ phase with only a few cells in the $G_{2}$ phase (22, 23). Furthermore, it has been suggested that growth of cells in the exponential phase is probably controlled in the $G_{1}$ phase while that of stationary phase is controlled in the $G_{2}$ phase (24). Precise mechanisms controlling growth remain to be elucidated.

The addition of Catron, a monoamine oxidase inhibitor, at 55 min after EHT resulted in inhibition of the incorporation of thymidine into DNA. The discrepancy between the results obtained with the atdition of adrenaline and those obtained with Catron remains unclarificd.

Acknowledgement: This investigation was supported in part by a grant from the Scientific Research Fund of the Ministary of Education of Japan in 1971.

\section{RLILRENCES}

1) Silye, II., Villiulx, R. anid Caytin, M.: Scichce 133, 44 (1961)

2) Brown-Grant, K.: Nature 191, 1076 (1961)

3) Barker, T.: Lxpl. Cell Re.s. 39, 355 (1965)

4) Bisfrga, R.: Life Sci. 5, 2033 (1966)

5) Bullougil, W.S.: Vitams. Horm. 13, 261 (1955)

6) Sakcma, K. and Terayama, H.: J. Biochem. 61, 504 (1967)

7) Javakidevi, K., Diwiy, V.C. Avis KidDer, G.W.: J. biol. Chem. 241, 2576 (1966)

8) Iwata, H., Kariya, K. axd Okamoto, H.: Experientia 27, 388 (1971)

9) I wata, H. ANd Kariya, K.: Experichia 29, 265 (1973)

10) SCHYEDFR, W.C.: J. biol. Chem. 164, 747 (1946)

11) Mejraum, W.: Z. physiol. Chem. 258, 117 (1939)

12) ClikiotT, G.: J. biol. Chom. 214, 297 (1952)

13) Iowry, O.H., Roserrougih, N.T., Farr, A.L., and Randall, R.J.: J. biol. Chem. 193, 265 (1951)

14) Bytefid, J.E. And Schirdaum, O.H.: Anal. Biochem. 17, 434 (1966)

15) Bulocgir, W.S. and Laurfance, E.B.: Proc. R. Soc. B. 154, 540 (1961)

16) Bulloggh, W.S. A\D Laurlancl, E.B.: Expl. Cell Res. 33, 176 (1964)

17) Iwata, H. aNd Kariya, K. : Japan. J. Pharmacol. (in press)

18) TAYLOR, E.W.: Expl. Cell Res. 40, 316 (1965)

19) Watanabe, Y. AND Inida, M.: Expl. Cell. Res. 39, 443 (1965)

20) Tobfy, R.A., Petrersey, D.F., Andirson, E.C. And Puck, T.T.: Biophys. J. 6,567 (1966)

21) Frankfurt, O.S.: Expl. Cell Res. 64, 140 (1971)

22) Comeron, J.E. and Clemann, G.: J. cell. Biol. 21, 196 (1964)

23) Argyris, T.S. nND Trimble, J.F.: Anat. Ree. 150, 1 (1964)

24) OKADA, S.: Kagaku 41, 58 (1971) (in Japancsc) 